www.mdpi.com/journal/remotesensing

Article

\title{
Estimating Cotton Nitrogen Nutrition Status Using Leaf Greenness and Ground Cover Information
}

\author{
Farrah Melissa Muharam ${ }^{1,2, *}$, Stephen J. Maas ${ }^{1}$, Kevin F. Bronson ${ }^{3}$ and Tina Delahunty ${ }^{4}$
}

1 Department of Plant and Soil Science, MS42122, Texas Tech University, Lubbock, TX 79409, USA; E-Mail: stephen.maas@ttu.edu

2 Department of Agriculture Technology, Faculty of Agriculture, Universiti Putra Malaysia, UPM Serdang, Selangor 43400, Malaysia

3 U.S. Arid-Land Agricultural Research Center, USDA-ARS, 21881 North Cardon Lane, Maricopa, AZ 85138, USA; E-Mail: Kevin.Bronson@ars.usda.gov

4 Department of Environmental, Geographical, and Geological Sciences, Bloomsburg University of Pennsylvania, 400 East 2nd Street, Bloomsburg, PA 17815, USA; E-Mail: tdelahun@bloomu.edu

* Author to whom correspondence should be addressed; E-Mail: farrahm@upm.edu.my; Tel.: +1-603-8947-4960; Fax: +1-603-8938-1015.

Academic Editors: Eyal Ben-Dor and Prasad S. Thenkabail

Received: 27 February 2015 / Accepted: 22 May 2015 / Published: 29 May 2015

\begin{abstract}
Assessing nitrogen (N) status is important from economic and environmental standpoints. To date, many spectral indices to estimate cotton chlorophyll or $\mathrm{N}$ content have been purely developed using statistical analysis approach where they are often subject to site-specific problems. This study describes and tests a novel method of utilizing physical characteristics of $\mathrm{N}$-fertilized cotton and combining field spectral measurements made at different spatial scales as an approach to estimate in-season chlorophyll or leaf $\mathrm{N}$ content of field-grown cotton. In this study, leaf greenness estimated from spectral measurements made at the individual leaf, canopy and scene levels was combined with percent ground cover to produce three different indices, named $\mathrm{TCC}_{\text {Leaf, }} \mathrm{TCC}_{\text {canopy, }}$ and $\mathrm{TCC}_{\text {Scene. These indices }}$ worked best for estimating leaf $\mathrm{N}$ at early flowering, but not for chlorophyll content. Of the three indices, $\mathrm{TCC}_{\text {Leaf }}$ showed the best ability to estimate leaf $\mathrm{N}\left(\mathrm{R}^{2}=0.89\right)$. These results suggest that the use of green and red-edge wavelengths derived at the leaf scale is best for estimating leaf greenness. TCC Canopy had a slightly lower $\mathrm{R}^{2}$ value than $\mathrm{TCC}_{\text {Leaf }}(0.76)$, suggesting that the utilization of yellow and red-edge wavelengths obtained at the canopy level could be used as an alternative to estimate leaf $\mathrm{N}$ in the absence of leaf spectral
\end{abstract}


information. The relationship between TCCscene and leaf $\mathrm{N}$ was the lowest $\left(\mathrm{R}^{2}=0.50\right)$, indicating that the estimation of canopy greenness from scene measurements needs improvement. Results from this study confirmed the potential of these indices as efficient methods for estimating in-season leaf $\mathrm{N}$ status of cotton.

Keyword: spectroradiometer; ground cover; nitrogen; leaf; canopy; scene

\section{Introduction}

For an indeterminate plant such as cotton, balancing its vegetative and reproductive growth is essential for optimum yield production. Acting as the most important nutrient required in cotton, optimum applications of nitrogen $(\mathrm{N})$ could achieve the balance. While deficient $\mathrm{N}$ could directly affect boll production and yield [1-5], excess $\mathrm{N}$ application could promote excessive vegetative growth [6]. Consequently, this excessive growth could lead to delayed boll maturity [7] and increased susceptibility to diseases and boll rot [8].

In the Western U.S., soil nitrate testing and plant tissue analysis are the common methods of evaluating in-season plant available $\mathrm{N}$ for cotton [9]. Despite reliability of the methods, their practical applications are limited by time of processing and cost. On that basis, alternative methods that cheap and real-time, for instance chlorophyll meters and spectrometry, have been assessed by researchers [10-30]. The use of chlorophyll meters at different cotton growth stages have been reported with varying results. At squaring, chlorophyll meter readings could be used to guide $\mathrm{N}$ fertilization rates [10]. At blooming, Bronson et al. [11] found that while chlorophyll meter readings were superior to petiole $\mathrm{NO}_{3}$ meter readings for assessing $\mathrm{N}$ status in cotton. On the other hand, Wiedenfeld et al. [12] reported that petiole sap readings were more closely related to $\mathrm{N}$ rate than leaf $\mathrm{N}$ or chlorophyll meter measurements. Rosolem and Van Meliss [13] and Malavolta et al. [14] found that the efficiency of a chlorophyll meter in distinguishing $\mathrm{N}$ contents was viable well into flowering. On the other hand, chlorophyll meter readings could be affected by variations in soil moisture $[14,15]$. Since the use of chlorophyll meters still requires contact with the leaf, its use for a large field with high $\mathrm{N}$ variability is time- and energy-consuming $[15,16]$.

Researchers have also used spectrometry to estimate leaf chlorophyll and N content [17-24]. Spectral analysis can be used to select the optimal wavelength(s) and indices for the estimation of leaf chlorophyll and $\mathrm{N}$. The theory underlying this method utilizes the strong absorptance peaks of chlorophyll in the red and blue wavelengths. Since leaf $\mathrm{N}$ is utilized by plants as a building block for chlorophyll, this latter parameter is often employed to indirectly estimate leaf $\mathrm{N}$ content.

In estimating chlorophyll or $\mathrm{N}$ nutrition of cotton, researchers have employed many strategies including selecting specific wavelengths that are sensitive to chlorophyll or $\mathrm{N}$ through statistical analysis, and using digital data from a range of sensors that acquire spectral reflectance at a variety of spatial resolutions. Buscaglia and Varco [25] found that leaf $\mathrm{N}$-sensitive wavelengths and consequently their correlation to cotton leaf $\mathrm{N}$ concentration changed according to the cotton growth stages, $612 \mathrm{~nm}$ at squaring or 728 at flowering. Zhao et al. [26] stated that the wavelengths at which leaf $\mathrm{N}$ are most responsive at were 517 and $701 \mathrm{~nm}$, the wavelengths changed to 551 and $708 \mathrm{~nm}$ for chlorophyll content. 
Read et al. [27] reported the wavelengths that were sensitive to leaf $\mathrm{N}$ concentration also shifted according to the spatial scale at which the reflectance measurement were made, for instance, 405, 585, 695, 755, 845 and $925 \mathrm{~nm}$ at the leaf scale and 410, 605 and $700 \mathrm{~nm}$ at the canopy scale. Studies by Li et al. [28] and Bronson et al. [29] also supported the finding related to the effects of spatial scale to the wavelengths shift. A recent study by Muharam [30] showed that the sensitivity of spectral wavelengths to $\mathrm{N}$ variations is profoundly dependent on the scale of the spectral measurement i.e., leaf, canopy and scene. However, the strongest relationship used to describe the variations in chlorophyll and $\mathrm{N}$ content were derived using reflectance measured at the canopy level [27]. This result has advantages since leaf nutrient data collection is commonly confined to a point basis, whereas reflectance algorithms might be more effective for estimating $\mathrm{N}$ at the landscape scale [29]. Tarpley et al. [31] stated that ratios constructed from green or yellow-orange wavelengths tended to overestimate leaf N. They suggested that this was because they were unable to detect the percentage of $\mathrm{N}$ due to possible confounding factors such as macro and micronutrient deficiencies and crop hybrids. While ratios developed from red-edge and NIR wavelengths were inclined to underestimate leaf $\mathrm{N}$ content, they had demonstrated both precision and accuracy characteristics. It is worth noting that other researchers such as Bronson et al. [10] and Buscaglia and Varco [25] found that cotton leaf $\mathrm{N}$ content and leaf or canopy reflectance exhibited a stronger relationship at the green wavelength rather than in the red-edge or NIR region.

It could be summarized that purely statistical analysis approach is subject to site-specific problems, where the specific wavelengths selected through this method to estimate the plant $\mathrm{N}$ status could change from one location to another. Likewise, these specific wavelengths vary at different scales of measurement, times of data acquisition and parameters of interest ( $\mathrm{N}$ or chlorophyll content). To overcome an issue of having a model calibrated according to specific sites, a new method to estimate chlorophyll or $\mathrm{N}$ content based on the physical characteristics or non-radiometric measurements of cotton plants as affected by $\mathrm{N}$ fertilization is proposed. The objective of this study is to test the ability of the method to estimate chlorophyll or leaf $\mathrm{N}$ content of field-grown cotton using field data from a two-year study conducted in 2010 and 2011.

\section{Materials and Methods}

\subsection{Theory}

Total Canopy Chlorophyll is the total amount of chlorophyll (in grams) in the leaf tissues of the plants comprising the canopy and can be determined as follows,

$$
\text { Total Canopy Chlorophyll }=\text { leaf chlorophyll } \times \text { total leaf area }
$$

where leaf chlorophyll is the chlorophyll content on a unit leaf area basis $\left(\mathrm{g} / \mathrm{m}^{2}\right)$ and the total leaf area of the canopy is measured in $\mathrm{m}^{2}$. From a remote sensing perspective, leaf chlorophyll is often related to leaf greenness. Since plants with high leaf N content tend to have high chlorophyll concentration [29], the chlorophyll will absorb more radiation in the blue and red wavelengths, resulting in lower reflectance in the green wavelengths (i.e., darker green leaves). Therefore, leaf greenness could be used as a proxy to indicate chlorophyll content of crops. Total leaf area could be also considered as proportional to leaf biomass. This parameter is related to Leaf Area Index (LAI) which can be estimated using remote 
sensing. Conceptually, Equation (1) could be re-written in terms of parameters that can be estimated using remote sensing as

Total Canopy Chlorophyll $\propto$ leaf greenness $\times$ biomass

Leaf Area Index (LAI) has been used as a surrogate for biomass by many researchers [32-36]. Utilizing remotely sensed data for estimating LAI, nevertheless, imposes 2 major challenges, which are (i) saturation of vegetation indices when the LAI exceeds 2, and (ii) LAI cannot be uniquely explained by one vegetation index, but rather additional functions such as chlorophyll content and/or other canopy characteristics [35]. In weighing alternatives for substituting LAI, Delegido et al. [37] discussed in depth that sensors used to estimate chlorophyll to estimate chlorophyll or $\mathrm{N}$ content are typically optical sensors, which operate using short wavelengths $(400 \mathrm{~nm}$ to $2500 \mathrm{~nm})$ of the electromagnetic spectrum. The optical sensors are mostly sensible to the top layer of LAI rather than by the entire LAI. We hypothesized that this LAI layer could be viewed by remote sensing imagers as a planar surface that is quantitatively described by ground cover. Therefore, this parameter defines the fraction of an area that is covered by plant canopy [38]. This is further supported by Delegido et al. [37], who found that the top layer of a canopy is the most photosynthetically active since it intercepts most of radiation. Thus, relating the top part of the canopy to optical remote sensing measurements is a reasonable approach.

The importance of ground cover in estimating $\mathrm{N}$ status using spectral approaches has not previously been emphasized, but it has been found to be more influential than canopy density in determining the values of scene reflectance or indices obtained at the scene scale [39,40]. In our models, percent ground cover is considered as a plant physiological measurement that has meaning only at the scene scale. In estimating leaf biomass as one of the essential factors affected by $\mathrm{N}$ fertilization, percent ground cover may be more useful than LAI. It is computationally less intensive than LAI since it has a finite range ( $0 \%$ to $100 \%)$, and is often linearly related to spectral indices [41]. For cotton, percent ground cover could be accurately estimated using a regular digital camera attached to a tethered blimp [42] or with medium-resolution multispectral satellite images [43]. Muharam et al. [44] reported that ground cover is not only related to plant $\mathrm{N}$ status but also shows a greater degree of separation between different $\mathrm{N}$ rates compared to plant height or width. Hence, we propose the use of ground cover to substitute for LAI in the following relationship for estimating chlorophyll content,

$$
\text { Total Canopy Chlorophyll } \propto \text { leaf greenness } \times \text { GC }
$$

where GC is ground cover expressed as a fraction ranging in value from 0 to 1 . In Equation (3), leaf greenness and GC must be considered independently of each other, since each term represents a different physical effect of $\mathrm{N}$ treatments, i.e., leaf color and canopy biomass. This basic equation is expected to amplify the effects of $\mathrm{N}$ treatments, where canopies with high chlorophyll content and ground cover should have high index values, and vice versa. On the other hand, if one of the terms has a low value, the index should be lower than for canopies with both high chlorophyll and ground cover. For instance, canopies with high chlorophyll content but low ground cover values or ones with low chlorophyll content but high ground cover. The form of Equation (3) also expresses the combination of spectral measurement with cotton physiological parameter measurements for the purpose of estimating leaf $\mathrm{N}$ or chlorophyll content.

To select the best spatial scales and wavelengths to estimate the leaf greenness term, Figure 1 is referred [30]. The spectral measurements were made at different spatial scales; leaf, canopy and scene 
at the cotton flowering stage (64 days after planting (DAP)) using a GER 1500 spectroradiometer, at Texas AgriLife and Extension Center in Halfway $\left(34.147^{\circ} \mathrm{N}, 101.948^{\circ} \mathrm{W}\right)$, in Hale County, TX, USA. Fertilizer $\mathrm{N}$ rates were 0,112 , and $224 \mathrm{~kg} \mathrm{ha}^{-1}$ applied using a ground applicator in a single UAN application $\left(320 \mathrm{~g} \mathrm{~N} \cdot \mathrm{kg}^{-1}\right)$.

At the leaf scale, $\mathrm{N}$ fertilization consistently affects reflectance at the $550 \mathrm{~nm}$ (green) and $700 \mathrm{~nm}$ (red-edge) wavelengths (see Figure 1a). From this figure, we note that the reflectance at 550 and $700 \mathrm{~nm}$ of $\mathrm{N}$-deficient plants is the highest for the three $\mathrm{N}$ treatments. In addition, we observe that, for each of the three $\mathrm{N}$ treatments, the effects on 550 and $700 \mathrm{~nm}$ reflectance are of similar magnitudes. On the other hand, $\mathrm{N}$ treatment effects are most pronounced at $600 \mathrm{~nm}$ (yellow) and $700 \mathrm{~nm}$ (red-edge) when the reflectance measurements were made at the canopy level (see Figure 1b). A similar observation to that described above could be made that $\mathrm{N}$-deficient plants had greater reflectance at the 600 and $700 \mathrm{~nm}$ wavelengths than fertilized $\mathrm{N}$ plants, and that the magnitude of the reflectance at these wavelengths is similar for each treatment. At the leaf and canopy scales, the reflectance measured in the visible region was primarily influenced by pigment concentration, such as chlorophyll.
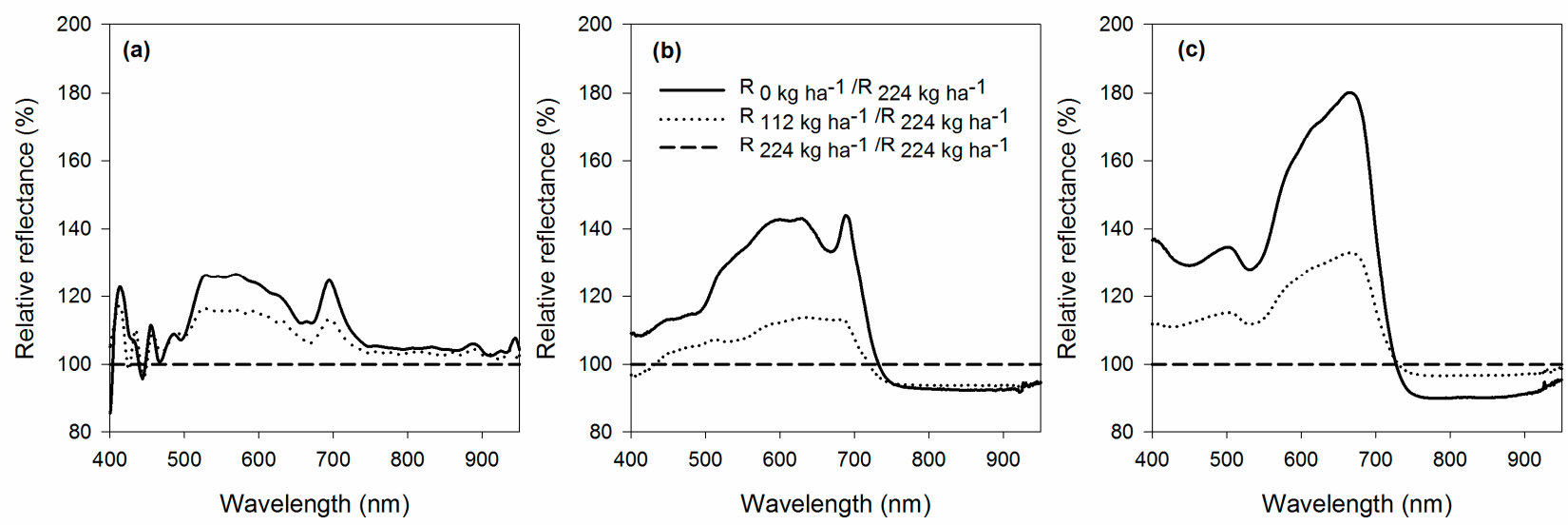

Figure 1. $\mathrm{N}$ treatment effects at different spatial scales (a) leaf, (b) canopy, and (c) scene.

As the amount of applied $\mathrm{N}$ increases, two observations can be made: (1) decreased reflectance at these wavelengths $(550,600$ and $700 \mathrm{~nm})$ for both of the measurements made at the leaf and canopy scales as a result of increasing chlorophyll content, (2) increased ground cover as more leaf biomass was produced. Since reflectance of fertilized plants in the green wavelengths is lower than for N-deficient plants, multiplying the low reflectance with high percent ground cover would cause these two effects to cancel. In order to avoid cancellation effects, the reciprocal of reflectance at the wavelengths associated with the $\mathrm{N}$ treatment effects is used. By using the reciprocal of the reflectance, fertilized N plants would have high leaf greenness values. Therefore, total canopy chlorophyll may be estimated either from reflectance measured at the leaf or canopy scales using the following relationships:

$$
\begin{gathered}
\text { Total Canopy Chlorophyll } \text { Leaf }_{\text {or TCC }} \mathrm{TCaf}=\left[1 /\left(\mathrm{R}_{550, \text { Leaf }}+\mathrm{R}_{700, \text { Leaf }}\right)\right] \times \mathrm{GC} \\
\text { Total Canopy Chlorophyll }{ }_{\text {Canopy }} \text { or TCC Canopy } \\
=\left[1 /\left(\mathrm{R}_{600, \text { Canopy }}+\mathrm{R}_{700, \text { Canopy }}\right)\right] \times \mathrm{GC}
\end{gathered}
$$

where $R_{550, \text { Leaf }}$ and $R_{700, \text { Leaf }}$ are the reflectance values at $550 \mathrm{~nm}$ and $700 \mathrm{~nm}$ obtained at the leaf scale, and $R_{600, C a n o p y}$ and $R_{700, C a n o p y}$ are the reflectance values at $600 \mathrm{~nm}$ and $700 \mathrm{~nm}$ measured at the canopy scale. Since $\left(\mathrm{R}_{700, \text { Leaf }}-\mathrm{R}_{550, \text { Leaf }}\right)$ of N-deficient plants $\approx\left(\mathrm{R}_{700, \text { Leaf }}-\mathrm{R}_{550, \text { Leaf }}\right)$ of N-ample plants, and 
$\left(\mathrm{R}_{550, \text { Leaf }}+\mathrm{R}_{700, \text { Leaf }}\right)$ of N-deficient plants $>\left(\mathrm{R}_{550, \text { Leaf }}+\mathrm{R}_{700, \text { Leaf }}\right)$ of N-ample plants, summing $\mathrm{R}_{550, \text { Leaf }}+\mathrm{R} 700$,Leaf would enhance the effects of leaf greenness. This approach (Equations (4) and (5)) indicates that two types of measurement are necessary, which are spectral information made at either the leaf or canopy scales, and ground cover made at the scene scale.

In situations where aerial or medium resolution satellite imagery can be acquired, we have proposed a method for estimating plant $\mathrm{N}$ status from this type of data. Since our results show that reflectance at the scene scale was primarily affected by ground cover, decomposition of scene reflectance into its canopy and soil components could be used to estimate the leaf greenness term at the scene level. For incomplete ground cover, reflectance contributed by the cotton canopy could be estimated by using a mixing model such as that proposed by Maas [39] as follows,

$$
\mathrm{R}_{\text {canopy }}=\left[\mathrm{R}_{\text {scene }}-\left(\mathrm{R}_{\text {soil }} \times(1-\mathrm{GC})\right)\right] / \mathrm{GC}
$$

where $R_{\text {canopy }}$ is the reflectance of the leaf canopy, $R_{\text {scene }}$ is the scene reflectance and $R_{\text {soil }}$ is the reflectance of the bare soil. If $\mathrm{GC}, \mathrm{R}_{\text {scene }}$ and $\mathrm{R}_{\text {soil }}$ are known, then $\mathrm{R}_{\text {canopy }}$ could be estimated. However, $\mathrm{R}_{\text {soil }}$ of a given soil type could vary with soil brightness, especially when the soil is shaded by plant canopy. In a case of incomplete ground cover, the bare soil reflectance in reality could be represented by the fraction of the soil surface between cotton rows that is sunlit, $g_{s u}$, and shaded, $g_{s h}$ :

$$
1-\mathrm{GC}=g_{s u}+g_{s h}
$$

Substituting $g_{s u}+g_{s h}$ into Equation (6) would yield new equations as follows,

$$
\begin{aligned}
& \mathrm{R}_{\text {canopy }}=\left[\mathrm{R}_{\text {scene }}-\left(\mathrm{R}_{\text {soil }} \times\left(g_{s u}+g_{s h}\right)\right)\right] / \mathrm{GC} \\
& \mathrm{R}_{\text {canopy }}=\left[\mathrm{R}_{\text {scene }}-\left(g_{s u} \mathrm{R}_{\text {soil }}+g_{s h} \mathrm{R}_{\text {soil }}\right)\right] / \mathrm{GC}
\end{aligned}
$$

$\mathrm{R}_{\text {soil }}$ in the portion of the equation involving $g_{s u}$ indicates that the reflectance is measured while the soil is illuminated, while $\mathrm{R}_{\text {soil }}$ in the portion of the equation involving $g_{s h}$ refers to the reflectance from the shaded fraction of the soil. If the reflectance measured under the former condition is expressed as $\mathrm{R}_{\text {sunlit }}$

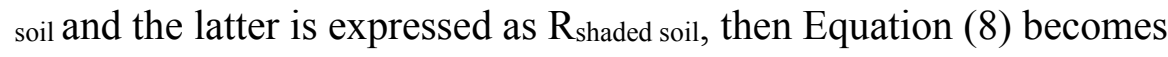

$$
\mathrm{R}_{\text {canopy }}=\left[\mathrm{R}_{\text {scene }}-\left(g_{s u} \mathrm{R}_{\text {sunlit soil }}+g_{s h} \mathrm{R}_{\text {shaded soil }}\right)\right] / \mathrm{GC}
$$

Substituting Equation (7) into Equation (9) results in the following equation,

$$
\mathrm{R}_{\text {canopy }}=\left[\mathrm{R}_{\text {scene }}-\left(g_{s u} \mathrm{R}_{\text {sunlit soil }}+\left(1-\mathrm{GC}-g_{s u}\right) \mathrm{R}_{\text {shaded soil }}\right)\right] / \mathrm{GC}
$$

At the scene scale, $\mathrm{N}$ fertilization mostly influenced reflectance in the $685 \mathrm{~nm}$ to $690 \mathrm{~nm}$ (red) and NIR regions (see Figure 1c). In comparison to fertilized plants, non-fertilized plants have higher reflectance in the red wavelengths, but lower reflectance in the NIR region. Therefore, the difference between NIR and red reflectance (RNIR - RRED) and normalization of this term to RNIR + RRED as accommodated by the NDVI could maximize the differences between $\mathrm{R}_{\text {canopy }}$ for different $\mathrm{N}$ fertilization rates. If the NDVI term serves as a surrogate for the leaf greenness term measured at the scene scale, then Equation (3) becomes

$$
\text { Total Canopy Chlorophyllscene }=\text { NDVI }_{\text {canopy }} \times \text { GC }
$$

Taking Equation (10) as a template to transform the absolute measurements made by using red and NIR wavelengths to a spectral index, we propose the following equation, 


$$
\mathrm{NDVI}_{\text {canopy }}=\left[\mathrm{NDVI}_{\text {scene }}-\left(g_{s u} \mathrm{NDVI}_{\text {sunlit soil }}+\left(1-\mathrm{GC}-g_{s u}\right) \mathrm{NDVI} \text { shaded soil }\right)\right] / \mathrm{GC}
$$

Or, by expanding the NDVI terms,

$$
\begin{gathered}
\left(\left(\mathrm{R}_{\mathrm{NIR}}-\mathrm{R}_{\mathrm{RED}}\right)_{\text {canopy }} /\left(\mathrm{R}_{\mathrm{NIR}}+\mathrm{R}_{\mathrm{RED}}\right)_{\text {canopy }}\right)=\left[\left(\left(\mathrm{R}_{\mathrm{NIR}}-\mathrm{R}_{\mathrm{RED}}\right)_{\text {scene }} /\left(\mathrm{R}_{\mathrm{NIR}}+\mathrm{R}_{\mathrm{RED}}\right)_{\text {scene }}\right)-\right. \\
\left(g_{\text {su }}\left(\left(\mathrm{R}_{\mathrm{NIR}}-\mathrm{R}_{\mathrm{RED}}\right)_{\text {sunlit soil }} /\left(\mathrm{R}_{\mathrm{NIR}}+\mathrm{R}_{\mathrm{RED}}\right)_{\text {sunlit soil }}\right)+\left(1-\mathrm{GC}-g_{s u}\right)\left(\left(\mathrm{R}_{\mathrm{NIR}}-\mathrm{R}_{\mathrm{RED}}\right)_{\text {shaded }}\right.\right. \\
\text { soil } \left.\left.\left./\left(\mathrm{R}_{\mathrm{NIR}}+\mathrm{R}_{\mathrm{RED}}\right)_{\text {shaded soil }}\right)\right)\right] / \mathrm{GC}
\end{gathered}
$$

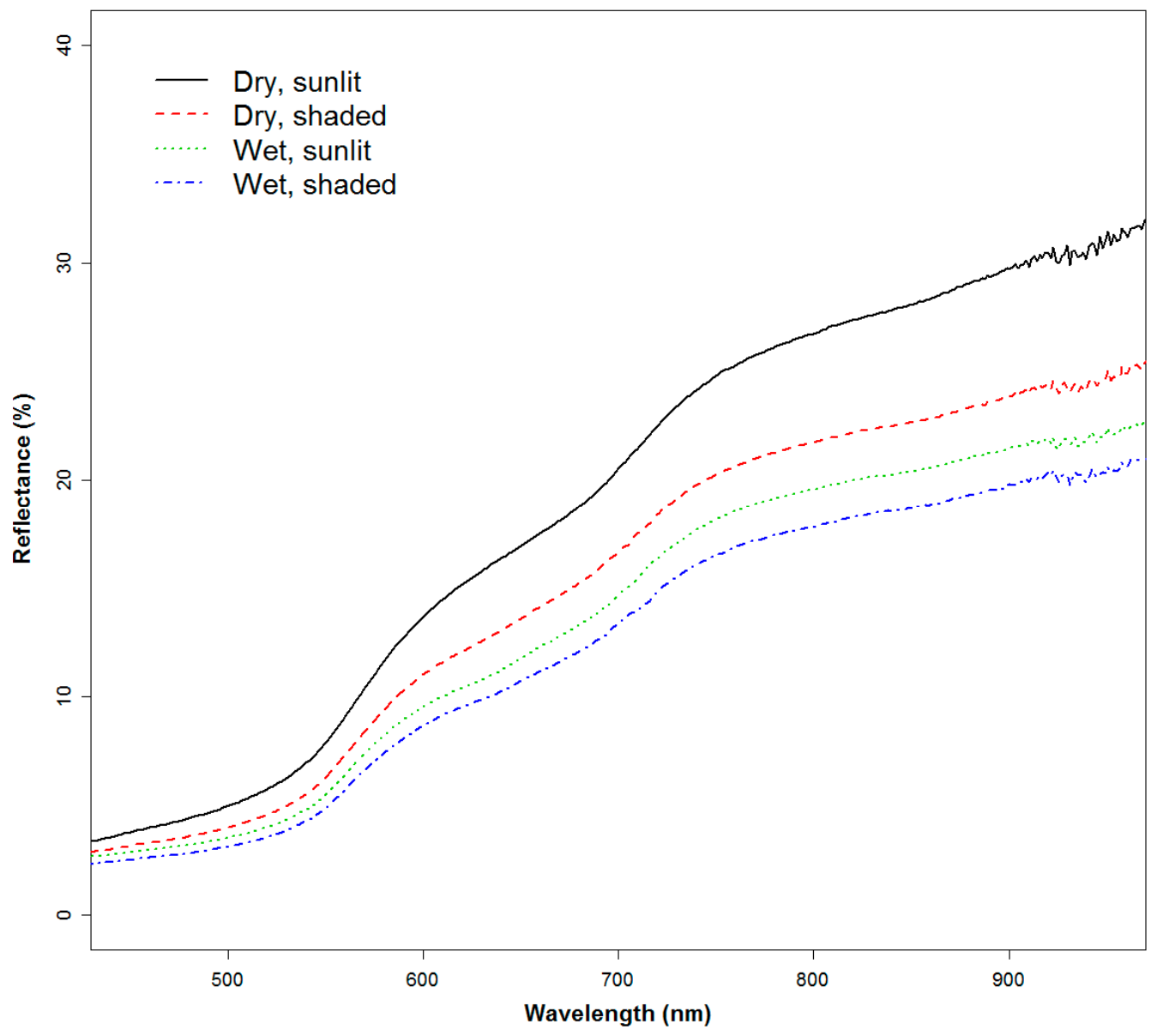

Figure 2. Soil reflectance under different soil moisture conditions and solar illumination.

Reflectance for different soil conditions is presented in Figure 2 [30]. The soil reflectance measurements were taken using a GER 1500 spectroradiometer on Pullman clay loam (thermic Torrertic Paleustolls) soil. For the wet soil reflectance measurement, $1 \mathrm{~L}$ of water was applied to saturate the soil surface. Dry soil that is sunlit or shaded within the sensor's field of view has reflectance that linearly increase from red to NIR wavelengths, even though the spectrum of shaded soil is slightly lower than that for sunlit, dry soil. Likewise, sunlit or shaded wet soil has a similar increasing pattern. In a situation where the difference of ( $\mathrm{R}_{\mathrm{NIR}}-\mathrm{R}_{\mathrm{RED}}$ ) between two soil conditions is maximum, which can occur when a fraction of $(1-\mathrm{GC})$ is wet and shaded, while the remaining fraction is dry and sunlit. In this situation, the value of ( $\left.R_{N I R}-R_{R E D}\right)$ dry,sunlit soil is 0.11 while ( $\left.R_{N I R}-R_{R E D}\right)_{\text {wet,shaded soil }}$ is 0.08 , indicating that the difference between these two values should be small. Therefore, we adopt the approach of Jiang et al. [45] who assume that ( $\left.\mathrm{R}_{\text {NIR }}-\mathrm{R}_{\mathrm{RED}}\right)_{\text {sunlit soil }} \approx\left(\mathrm{R}_{\mathrm{NIR}}-\mathrm{R}_{\mathrm{RED}}\right)_{\text {shaded soil. Figure } 2 \text { demonstrates }}$ 
that $\left(\mathrm{R}_{\mathrm{NIR}}+\mathrm{R} \mathrm{RED}\right)_{\text {sunlit soil }}>\left(\mathrm{R}_{\mathrm{NIR}}+\mathrm{R}_{\mathrm{RED}}\right)_{\text {shaded soil, so that }} \mathrm{NDVI}_{\text {sunlit }}<\mathrm{NDVI}_{\text {shaded soil }}$ when $\left(\mathrm{R}_{\text {NIR }}-\mathrm{R}_{\mathrm{RED}}\right)_{\text {sunlit soil }} \approx\left(\mathrm{R}_{\mathrm{NIR}}-\mathrm{R}_{\mathrm{RED}}\right)_{\text {shaded soil. }}$ Therefore, if the NDVI formulation were used as in Equation (12), the equation would be biased towards variations in soil conditions. To eliminate this bias so that the model could be implemented under various soil conditions, the normalization term is removed from Equation (12). The new form of Equation (12) becomes

$$
\begin{gathered}
\left(\mathrm{R}_{\mathrm{NIR}}-\mathrm{R}_{\mathrm{RED}}\right)_{\text {canopy }}=\left[\left(\mathrm{R}_{\mathrm{NIR}}-\mathrm{R}_{\mathrm{RED}}\right)_{\text {scene }}-g_{s u}\left(\mathrm{R}_{\mathrm{NIR}}-\mathrm{R}_{\mathrm{RED}}\right)_{\text {sunlit soil }}-\left(1-\mathrm{GC}-g_{s u}\right)\left(\mathrm{R}_{\mathrm{NIR}}\right.\right. \\
\left.\left.\left.-\mathrm{R}_{\mathrm{RED}}\right)_{\text {shaded soil }}\right)\right] / \mathrm{GC}
\end{gathered}
$$

For simplification, let's replace $\left(\mathrm{R}_{N I R}-\mathrm{R}_{\mathrm{RED}}\right)_{\text {sunlit soil }}$ and $\left(\mathrm{R}_{\mathrm{NIR}}-\mathrm{R}_{\mathrm{RED}}\right)$ shaded soil with the parameter $a$. This would yield a new set of equations,

$$
\begin{gathered}
\left(\mathrm{R}_{\mathrm{NIR}}-\mathrm{R}_{\mathrm{RED}}\right)_{\text {canopy }}=\left[\left(\mathrm{R}_{\mathrm{NIR}}-\mathrm{R}_{\mathrm{RED}}\right)_{\text {scene }}-g_{s u} a-\left(1-\mathrm{GC}-g_{s u}\right) a\right] / \mathrm{GC} \\
\left(\mathrm{R}_{\mathrm{NIR}}-\mathrm{R}_{\mathrm{RED}}\right)_{\text {canopy }}=\left[\left(\mathrm{R}_{\mathrm{NIR}}-\mathrm{R}_{\mathrm{RED}}\right)_{\text {scene }}-a\left(g_{s u}+1-\mathrm{GC}-g_{s u}\right)\right] / \mathrm{GC} \\
\left(\mathrm{R}_{\mathrm{NIR}}-\mathrm{R}_{\mathrm{RED}}\right)_{\text {canopy }}=\left[\left(\mathrm{R}_{\mathrm{NIR}}-\mathrm{R}_{\mathrm{RED}}\right)_{\text {scene }}-a(1-\mathrm{GC})\right] / \mathrm{GC}
\end{gathered}
$$

Since $\left(\mathrm{R}_{\mathrm{NIR}}-\mathrm{R}_{\mathrm{RED}}\right)_{\text {sunlit soil }} \approx\left(\mathrm{R}_{\mathrm{NIR}}-\mathrm{R}_{\mathrm{RED}}\right)_{\text {shaded soil, then Equation }(17) \text { becomes }}$

$$
\left(\mathrm{R}_{\mathrm{NIR}}-\mathrm{R}_{\mathrm{RED}}\right)_{\text {canopy }}=\left[\left(\mathrm{R}_{\mathrm{NIR}}-\mathrm{R}_{\mathrm{RED}}\right)_{\text {scene }}-\left(\mathrm{R}_{\mathrm{NIR}}-\mathrm{R}_{\mathrm{RED}}\right)_{\text {soil }}(1-\mathrm{GC})\right] / \mathrm{GC}
$$

Modifying Equation (10) results in the following,

$$
\text { Total Canopy Chlorophyllscene }=\left(\mathrm{R}_{\mathrm{NIR}}-\mathrm{R}_{\mathrm{RED}}\right)_{\text {canopy }} \times \mathrm{GC}
$$

where the (RNIR-RRED) canopy term is known as the Difference Vegetation Index (DVI). This term could be estimated if the reflectance of scene and soil at red and NIR wavelengths, along with ground cover, are known. Combining Equations (18) and (19) results in the following equation,

$$
\text { Total Canopy Chlorophyllscene }=\left(\mathrm{R}_{\mathrm{NIR}}-\mathrm{R}_{\mathrm{RED}}\right)_{\text {scene }}-\left[\left(\mathrm{R}_{\mathrm{NIR}}-\mathrm{R}_{\mathrm{RED}}\right)_{\mathrm{soil}}(1-\mathrm{GC})\right]
$$

Since the product of Equation (20) can be small (on the order of 0.01), it can be multiplied by 100 so that the value of TCCscene is reasonably large. Finally, Equation (20) becomes

$$
\begin{gathered}
\text { Total Canopy Chlorophyllsceneor TCC } \text { Scene }=\left[\left(\mathrm{R}_{\mathrm{NIR}}-\mathrm{R}_{\mathrm{RED}}\right)_{\text {scene }}-\left[\left(\mathrm{R}_{\mathrm{NIR}}-\mathrm{R}_{\mathrm{RED}}\right)_{\text {soil }}(1-\right.\right. \\
\mathrm{GC})]] \times 100
\end{gathered}
$$

Since N-ample plants consistently result in lower red reflectance and higher NIR reflectance than $\mathrm{N}$-deficient plants, the $\left(\mathrm{R}_{\mathrm{NIR}}-\mathrm{R}_{\mathrm{RED}}\right)_{\text {canopy }}$ term would be maximized for the former, so that no reciprocal value is required (as opposed to Equations (4) and (5)). Through Equations (4), (5) and (21), the product of leaf greenness and GC amplify the fertilization effects represented by canopy color and biomass.

\subsection{Experimental Sites and Designs}

In 2010, two separate experiments were conducted at the Texas Tech University Quaker Avenue Research Farm $\left(33.598^{\circ} \mathrm{N}, 101.906^{\circ} \mathrm{W}\right)$ and the Texas AgriLife Research and Extension Center $\left(33.690^{\circ} \mathrm{N}\right.$ and $\left.101.827^{\circ} \mathrm{W}\right)$ in Lubbock County, TX, USA [45]. Henceforth, these sites will be referred to as Station 1 and Station 2, respectively. In 2011, a study site at the Texas AgriLife and Extension Center in Halfway $\left(34.147^{\circ} \mathrm{N}, 101.948^{\circ} \mathrm{W}\right)$, in Hale County, TX, USA was used. Hereafter, this site will be referred to as Station 3. The $\mathrm{N}$ fertilization rates were varied by study site due to original objectives of these independent studies. 
The soil types at Station 1, 2 and 3 are Acuff sandy clay loam, Lubbock sandy clay and Pullman clay loam, respectively (USDA-NCRS, 2011). Station 1 was furrow-irrigated, while sub-surface drip irrigation (SDI) was used to irrigate Station 2 and 3. The drip tapes were spaced at 2-m in the middle of alternate furrows at $30-\mathrm{cm}$ depth with emitters spaced at $60-\mathrm{cm}$. Rate of irrigation was $1 \mathrm{~L} \mathrm{~min}^{-1}$ at $0.08 \mathrm{MPa}$.

The experiment at Station 1 was conducted as Randomized Complete Block Design (RCBD) with 3 levels of $\mathrm{N}$ rates and 4 blocks (replicates). The site was planted with FiberMax 9170 on 20 May 2010, in 16, 1-m rows that were 52-m long. Fertilizer $\mathrm{N}$ rates were 0,67 and $134 \mathrm{~kg} \cdot \mathrm{ha}^{-1}$ representing zero, intermediate and high $\mathrm{N}$ rates as determined using soil-based tests for recommended yields. Fertilizer $\mathrm{N}$ was applied as Urea Ammnioum Nitrate (UAN) $\left(320 \mathrm{~g} \mathrm{~N} \cdot \mathrm{kg}^{-1}\right)$ in two equal knife applications on 14 June (25 DAP) and 19 July (60 DAP) 2010. The fertilization was followed immediately by irrigation.

The experimental design at Station 2 was factorial Randomized Incomplete Block Design with 3 blocks (replicates), where the zero treatment had only 2 replications. There were 2 cotton varieties planted at this site, Fibermax 9180 and Stoneville 5458, in 1-m rows that were 180-m long. Fertilizer N rates consisted of zero $\mathrm{N}$, a reflectance-based $\mathrm{N}$ rate $\left(50 \mathrm{~kg} \cdot \mathrm{ha}^{-1}\right)$ and a soil test-based $\mathrm{N}$ rate $\left(101 \mathrm{~kg} \cdot \mathrm{ha}^{-1}\right)$ as adapted by Bronson et al. [8]. Each plot consisted of 8 rows that were supplied by an individual irrigation and fertilizer injection station. Liquid UAN (320 $\left.\mathrm{g} \mathrm{N} \mathrm{kg}^{-1}\right)$ was applied using the SDI for five weeks starting from 33 DAP to 64 DAP for five days per week until the total rates were achieved. To ensure optimum $\mathrm{pH}$ level of the irrigation water and to avoid precipitation of $\mathrm{CaCO}_{3}$, $\mathrm{H}_{2} \mathrm{SO}_{4}\left(25 \mathrm{~g} \cdot \mathrm{kg}^{-1}\right)$ was injected continuously into the irrigation water.

The experimental design at Station 3 was RBD with 5 blocks or replicates. On 14 June 2011, DP 104 B2RF (Delta Pine 104 Bollgard II Roundup-Ready Flex) was planted at this site in 16 rows times 37-m plots, on 80 -cm rows. Fertilizer $\mathrm{N}$ rates were 0,112 , and $224 \mathrm{~kg} \cdot \mathrm{ha}^{-1}$ determined using soil-based tests for recommended yields. The $\mathrm{N}$ fertilization was knifed into the soil $10 \mathrm{~cm}$ off the plant row in a single UAN application (320 $\mathrm{g} \mathrm{N} \cdot \mathrm{kg}^{-1}$ ) using a ground applicator on 3 August 2011 (50 DAP).

\subsection{Data Acquisition}

In 2010, plant physiological and reflectance data were measured from 9 July to 5 September, starting at the cotton squaring stage until the development of green bolls. Due to abnormally wet year in 2010, measurements were made seven times at Station 1 during that period while, for Station 2, measurements were made on five sampling dates. In 2011, measurement dates were from 28 June to 31 August, starting at the eighth true leaf stage. In that year, physiological and reflectance data were collected every two weeks resulting in five sampling dates.

Plant physiological and reflectance data measured during the field work campaign were chlorophyll meter reading (SPAD unit), percent ground cover, leaf $\mathrm{N}$ (\%), leaf reflectance, canopy reflectance, and scene reflectance. These measurements were made as close together temporally as possible to avoid changes in $\mathrm{N}$ effects and general crop condition between one set of data and the next.

\subsubsection{Plant Physiological Data}

Chlorophyll readings were obtained using a Minolta SPAD 502 Chlorophyll Meter (Minolta Corp., Osaka, Japan) early in the morning. At Station 1 and 2, 25 upper recently matured leaves per plot were sampled. At Station 3, the fifth leaf off of main stem was used, with a similar sample number per 
replication. The same leaf blades were later dried at $65^{\circ} \mathrm{C}$ for 96 hours and ground to $0.5 \mathrm{~mm}$ for leaf $\mathrm{N}$ analysis. In 2010, a LECO FP-528 Protein N Analyzer (LECO Corp., St. Joseph, MI, USA) was used to perform this analysis, and a LECO Tru-Spec CN (LECO Corp., St. Joseph, MI, USA) was used in 2011. Overhead photographs used to evaluate ground cover (GC) were acquired using a Kodak digital camera, model EasyShare C1530 (Eastman Kodak Company, Rochester, NY, USA). The estimation of ground cover was made by dividing the number of pixels in the image representing plant canopy by the total image pixels $[43,44]$. This processing was done using Adobe Photoshop software (Adobe System Inc., San Jose, CA, USA) where canopy pixels were selected using the Select Range toolbox, and pixels associated with volunteer plants, weeds, plant litter and shadow were visually eliminated. Three to six images were taken in each plot.

\subsubsection{Reflectance Data}

Reflectance measurements were taken using a GER 1500 portable field spectroradiometer (Spectra Vista Corp., Poughkeepsie, NY, USA). The spectroradiometer has a spectral range from $290 \mathrm{~nm}$ to $1030 \mathrm{~nm}$ with a sampling interval of $1.5 \mathrm{~nm}$. The instrument has a $4^{\circ}$ field of view (FOV).

Leaf reflectance was taken on individual leaves. Immediately after the chlorophyll meter measurements, the 25 sampled leaves were quickly measured for leaf reflectance with the aid of an integrating sphere (LI-COR Inc., Lincoln, NE, USA) to avoid wilting of leaves and thus no chilling was required. The use of the integrating sphere was intended to achieve uniform, hemispherical illumination of the leaves. The sphere was connected to the GER 1500 spectroradiometer via a fiber optical wire and illuminated by a $10-\mathrm{W}$ halogen bulb powered by a $12 \mathrm{~V}$ battery. The leaf blade was placed over the sampling port of the integrating sphere with the upper surface facing the inside of the sphere.

Canopy reflectance was defined as the reflectance of the top of the leaf canopy excluding the background soil between the rows of plants. These measurements were obtained by positioning the spectroradiometer at a consistent height of $50 \mathrm{~cm}$ above the top of the plant canopy, centered on the plant row. The spectroradiometer had an angular FOV of $4^{\circ}$, so approximately $10 \mathrm{~cm}^{2}$ of leaf canopy was observed in each measurement. At least 10 canopy reflectance measurements were made along the centerline of the plant row. These individual measurements were averaged to produce a composite value of canopy reflectance. Using this procedure rather than a single measurement of canopy reflectance using an instrument with a wider FOV insures that the measurements do not include any of the bare soil between the rows of plants, and eliminates optical distortion of the target near the outer edge of the measured area due to perspective effects that can be present in observations from instruments with wide FOVs. Measurements were made on clear days, with the time of data collection ranging from two hours before to two hours after local solar noon. A white reference panel was used to calibrate the spectroradiometer prior to the collection of canopy reflectance in each plot.

Scene reflectance is analogous to the reflectance value of a pixel from a satellite or aerial image and includes the mixed effects of the surfaces within the pixel. It was derived by averaging individual reflectance measurements made every $5-\mathrm{cm}$ along a transect spanning from one row of the crop to the next according to the design described by Maas [39]. This resulted in a set of 21 measurements for $100-\mathrm{cm}$ rows and 17 measurements for $80-\mathrm{cm}$ rows. A portable frame with a horizontal bar marked every $5 \mathrm{~cm}$ assisted in transect measurements. In 2010, measurements were taken at two low- and two high-N treatment plots. In 2011, scene reflectance was measured in each plot, which totaled up to 27 measurements. 
The reflectance (spectroradiometer) data were imported into Microsoft Excel 2007 (Microsoft Corp., Redmond, WA, USA). The columns of the raw data represented wavelength, target (leaf, canopy, or scene) radiance, and reference panel radiance. Reflectance values were calculated by dividing target radiance by reference radiance.

The leaf spectrum for each treatment was re-sampled from the original spectroradiometer wavelengths to $10-\mathrm{nm}$ intervals to reduce inherent noise in the original data, resulting in a smoothed spectrum. Canopy and scene measurements, however, were excluded from this processing. The spectra were averaged for each replication, each treatment and each week in order to obtain a single spectrum. Manual examination was performed on each canopy spectrum to exclude those with significant contributions from background soil. Scene reflectance at a given wavelength was derived by averaging across the entire transect, which included measurements over soil and plant canopy. Finally, scene reflectance was calculated at two different wavebands which were involved in the Equation (21): 640 to $680 \mathrm{~nm}$ (red) and 800 to $900 \mathrm{~nm}$ (NIR) by averaging the reflectance value within these wavelength ranges.

\subsection{Statistical Analysis}

PROC CORR in SAS Ver. 9.2 (SAS Institute, 2008) was used to evaluate and test the Pearson correlation coefficient ( $\mathrm{r}$ ) between the leaf greenness and chlorophyll meter readings. PROC REG was used to derive linear regression coefficients, which included the slope, intercept, and coefficient of linear regression $\left(\mathrm{r}^{2}\right)$, between the TCCs and plant $\mathrm{N}$ indicators.

\section{Results and Discussion}

\subsection{Correlations between Leaf Greenness and Chlorophyll Meter Readings}

To examine if leaf greenness could be used as a proxy for chlorophyll content of cotton, $r$ values describing the strength of the correlation between leaf greenness and chlorophyll meter readings were evaluated (Table 1). In general, leaf greenness measured at the leaf scale was significantly, positively correlated with chlorophyll meter readings at all growth stages prior to green bolls $(r=0.66$ to 0.90$)$. An exception was leaf greenness obtained at Station 2, where it was not significantly correlated with chlorophyll meter readings. While many of the relationships between chlorophyll meter readings and leaf greenness measured at the leaf scale were significant at $P$ value $=0.0001$, the relationship between leaf greenness measured at the canopy scale and chlorophyll meter readings was significant from late squaring to late flowering ( $\mathrm{r}=0.77$ to 0.95$)$ at most of the experimental sites and sampling dates at lower $P$ values. At Station 1, leaf greenness measured at the canopy scale was negatively correlated with chlorophyll meter readings at late flowering and green bolls. The opposite pattern was observed at Station 2 for cultivar SV5458, where the negative correlation was shown early in the season. For the leaf greenness estimated at the scene scale, weaker relationships were illustrated in most sampling dates in comparison to the leaf greenness obtained at the other spatial scales, except for Station 2 later in the season. The fact that chlorophyll meter readings were correlated better with the leaf greenness measured at the leaf and canopy scale than scene scale suggests that the reflectance obtained at the leaf and canopy level contains the purest signals related to chlorophyll contents, and to a lesser degree at the scene scale. Nevertheless, it is not clear why the correlations between chlorophyll meter readings and leaf greenness 
were weak at the leaf level at Station 2, but strong for the canopy and scene level. This result is probably related to the greater ground cover, canopy widths and plant height at that site year [44].

Table 1. Coefficient of Pearson correlation between leaf greenness measured at leaf (Leaf greennessLeaf), canopy (Leaf greennesscanopy) and scene (Leaf greennessScene) scales with chlorophyll meter readings. Number of samples for weekly correlation analysis was 8,5 , and 10 for Station 1, Station 2 (each cultivars), and Station 3, respectively. In certain weeks, the analysis was not carried out due to insufficient number of samples.

\begin{tabular}{|c|c|c|c|c|}
\hline Station, Cultivar, Year & Growth Stage & Leaf GreennessLeaf & Leaf Greenness Canopy & Leaf Greennessscene \\
\hline \multirow{6}{*}{ Station 1, FM9170, 2010} & MS & $0.68 * *$ & 0.48 & -0.17 \\
\hline & MS & 0.16 & 0.44 & -0.14 \\
\hline & LS & $0.90 * * * *$ & $0.84 * * * *$ & -- \\
\hline & $\mathrm{EF}$ & $0.66 * *$ & $0.54 *$ & -- \\
\hline & $\mathrm{LF}$ & -0.40 & $-0.57 *$ & -- \\
\hline & GB & -0.17 & $-0.67 * *$ & -0.66 \\
\hline \multirow{5}{*}{ Station 2, FM9180, 2010} & MS & -0.05 & 0.19 & -- \\
\hline & LS & $0.75 * *$ & $0.70 *$ & -- \\
\hline & $\mathrm{EF}$ & 0.17 & $0.92 * * *$ & -- \\
\hline & $\mathrm{LF}$ & 0.48 & $0.95 * * * *$ & -- \\
\hline & GB & 0.56 & $0.64 *$ & -- \\
\hline \multirow{5}{*}{ Station 2, SV5458, 2010} & MS & 0.01 & -0.37 & -- \\
\hline & LS & -0.38 & $0.77 * *$ & -- \\
\hline & $\mathrm{EF}$ & 0.53 & $0.67 *$ & $0.99 * * *$ \\
\hline & $\mathrm{LF}$ & 0.44 & $0.84 * * *$ & $-0.97 * *$ \\
\hline & GB & -0.58 & $0.84 * *$ & -0.84 \\
\hline \multirow{5}{*}{ Station 3, DP1044 2011} & ES & $0.84 * * * *$ & 0.24 & 0.36 \\
\hline & LS & $0.83 * * * *$ & $0.80 * * * *$ & $0.60 * *$ \\
\hline & $\mathrm{EF}$ & $0.81 * * * *$ & $0.64 * *$ & 0.21 \\
\hline & $\mathrm{LF}$ & $0.82 * * * *$ & $0.69 * * *$ & 0.20 \\
\hline & GB & 0.40 & 0.24 & -0.26 \\
\hline
\end{tabular}

$*, * *, * * *, * * * *$ denote significant levels ( $P$-value) at $0.05,0.01,0.001$, and 0.0001 , respectively. MS, mid-squaring;

ES, early squaring; LS, late squaring; EF, early flowering, LF, late flowering; and GB, green bolls.

\subsection{Assessment of TCCs According to Growth Stages and Plant N Status}

In order to evaluate the optimum timing for using TCCs, data points from all experimental sites were pooled according to two crucial growth stages (mid to late squaring and early flowering). The performance of the TCCs against leaf $\mathrm{N}$ and chlorophyll meter readings was measured through the coefficient of linear regression $\left(\mathrm{r}^{2}\right)$ (Figures 3-8).

In comparing the two growth stages, TCCs performed better at early flowering (Figures $3 b, 4 b, 5 b, 6 b$, and $8 \mathrm{~b}$ ) than at mid to late squaring (Figures $3 \mathrm{a}, 4 \mathrm{a}, 5 \mathrm{a}, 6 \mathrm{a}$, and $8 \mathrm{a}$ ). For example, the $\mathrm{r}^{2}$ values for the relationship between the TCCs at early flowering and leaf $\mathrm{N}$ ranged from 0.50 to 0.89 (Figures $3 \mathrm{~b}, 5 \mathrm{~b}$ and $7 \mathrm{~b}$ ). In contrast, at mid to late squaring, the $\mathrm{r}^{2}$ values were poor and weak ( 0.15 to 0.18 ), except for TCCscene which had an $\mathrm{r}^{2}$ of 0.53 (Figures 3a, 5a and 7a). This finding agreed with recent reports by 
Bronson et al. [10] and Buscaglia and Varco [25], who found that the estimation of leaf $\mathrm{N}$ by using spectral indices and/or chlorophyll meter readings produced better results at early flowering than at early squaring.
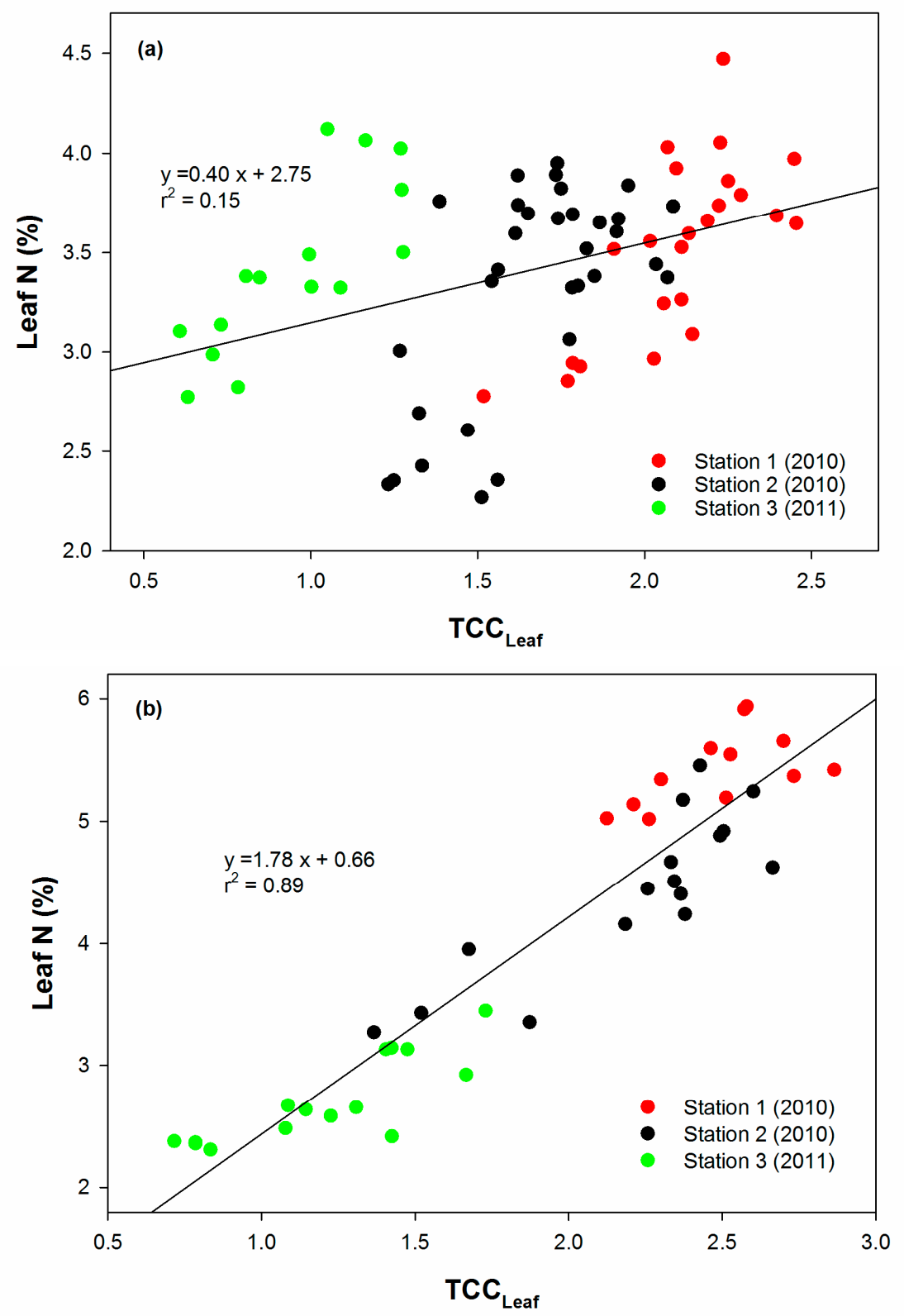

Figure 3. Linear regression between $\mathrm{TCC}_{\mathrm{Leaf}}$ and leaf $\mathrm{N}$ at (a) mid to late squaring, and (b) early flowering.

It is also worth mentioning that, at early flowering, three clusters of data points representing each station were situated close to the regression line, especially for TCC $\mathrm{Leaf}_{\text {and }}$ TCC Canopy. This crucial finding suggests that TCCs at early flowering are not site- and environment-specific, considering the extremes in weather conditions that occurred at those experimental locations [44]. For example, for the relationship between TCC $_{\text {Leaf }}$ or TCC Canopy and leaf N, four data points from Station 2 overlapped the data points from Station 3. These four data points were from zero $\mathrm{N}$ plots $(3.2 \%$ to $3.6 \%$ of $\mathrm{N})$ that received abundant of rainfall in 2010. Data points from Station 3, regardless of the $\mathrm{N}$ treatment, had low $\mathrm{N}$ averages $(2.4 \%$ to $3.2 \%)$ due to the low $\mathrm{N}$ uptake in the water-stressed 2011 growing season. The rest of the data points from Station 2 
overlapped the data points from Station 1, where they had relatively high $\mathrm{N}$ content ( $4.4 \%$ to $5.7 \%)$. On the other hand, data points plotted during mid-squaring constituted individual clusters according to the experimental station. Each cluster could be fit with a separate regression line. Two distinct data clusters representing different weather conditions also could have their own regression line. As discussed by Muharam et al. [44], experiments in 2010 were conducted during abnormally wet and cool growing conditions, where total rainfall received was $213 \mathrm{~mm}$ and temperatures were lower than the 10-year average. This weather condition was distinctly reflected through high TCCs values by the formation of a cluster from the measurement points made at Station 1 and 2. However, in 2011, the growing conditions were extremely dry and hot as compared to historical data, with only $42 \mathrm{~mm}$ of rainfall recorded. Consequently, a cluster of lower TCC points from Station 3 was evidently separated from the 2010 cluster of points. Additionally, this observation becomes more apparent for the chlorophyll meter readings than for the leaf $\mathrm{N}$.
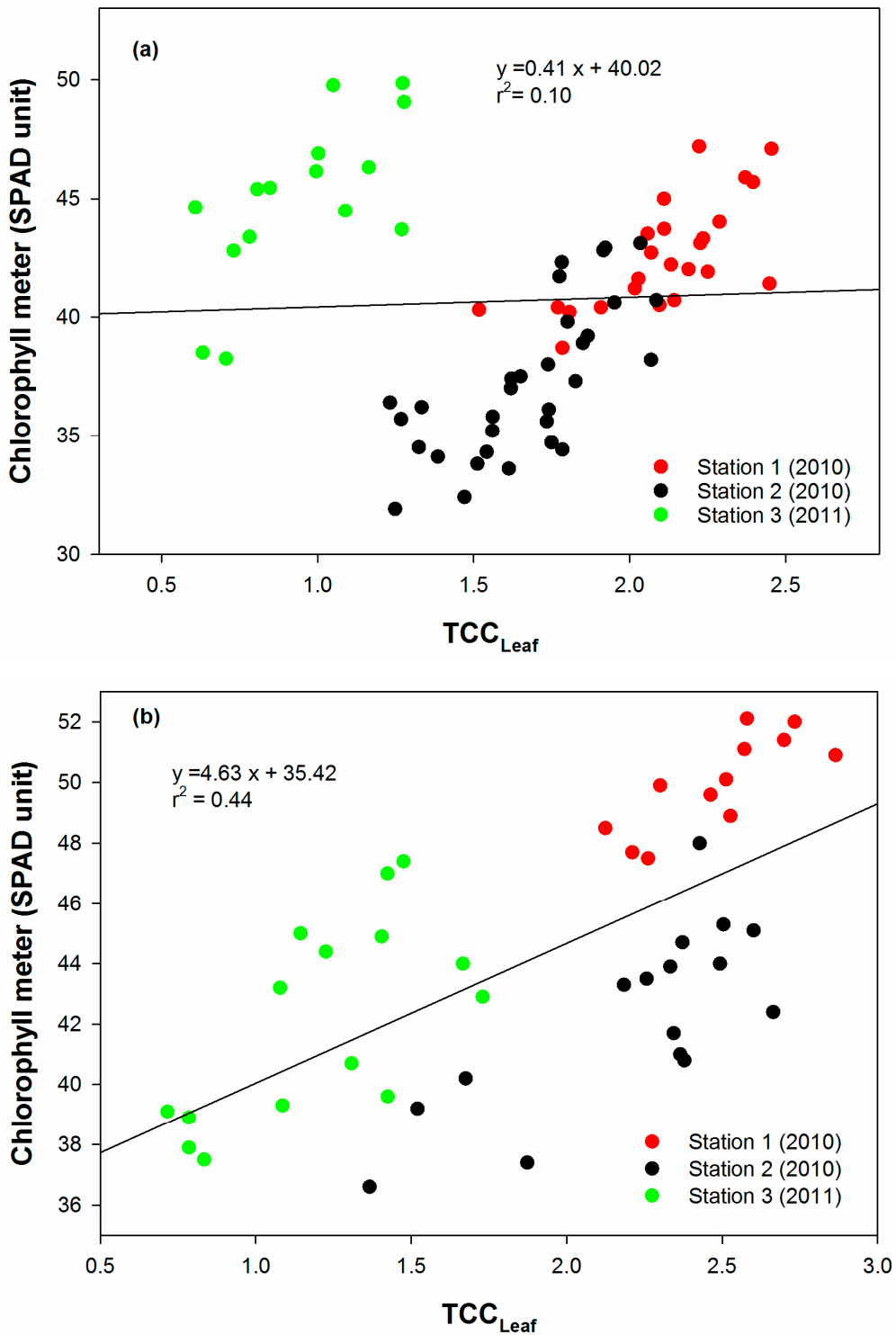

Figure 4. Linear regression between TCC $\mathrm{Leaf}_{\text {and }}$ chlorophyll meter readings at (a) mid to late squaring, and (b) early flowering. 
Total Chlorophyll Content (TCC) indices also were better at estimating leaf $\mathrm{N}$ than estimating chlorophyll meter readings (Figures 3-8). For the chlorophyll meter readings, the $r^{2}$ values describing the relationship between TCCs and this parameter were significantly lower ( 0.00 to 0.44$)$ than for leaf $\mathrm{N}$ (0.15 to 0.89) (Figures 4, 6 and 8). Better linear relationships between TCCs and leaf $\mathrm{N}$ could be explained by the fact that the confounding effects of water, intercellular and cell structures in the dried, ground tissue used for measuring leaf $\mathrm{N}$ had been completely removed. In fresh tissue, water status and leaf thickness could confound the reflectance at the NIR wavelengths $[18,46]$ at which the SPAD chlorophyll meter operates. Wood et al. [47] also suggest that the chlorophyll meter appeared to be a less effective predictor of $\mathrm{N}$ cotton status than standard tissue tests.
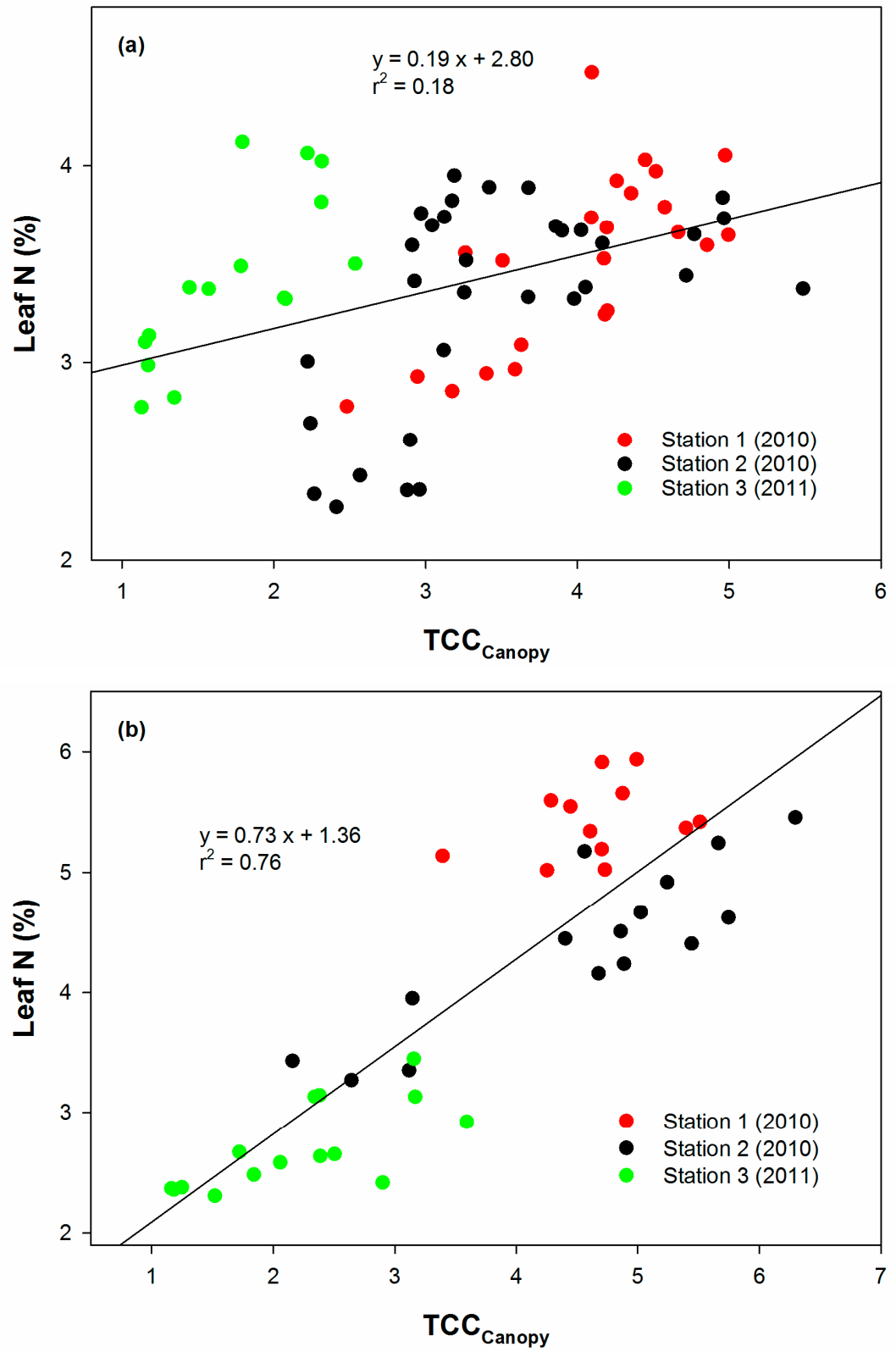

Figure 5. Linear regression between $\mathrm{TCC}$ Canopy and leaf $\mathrm{N}$ at (a) mid to late squaring, and (b) early flowering. 

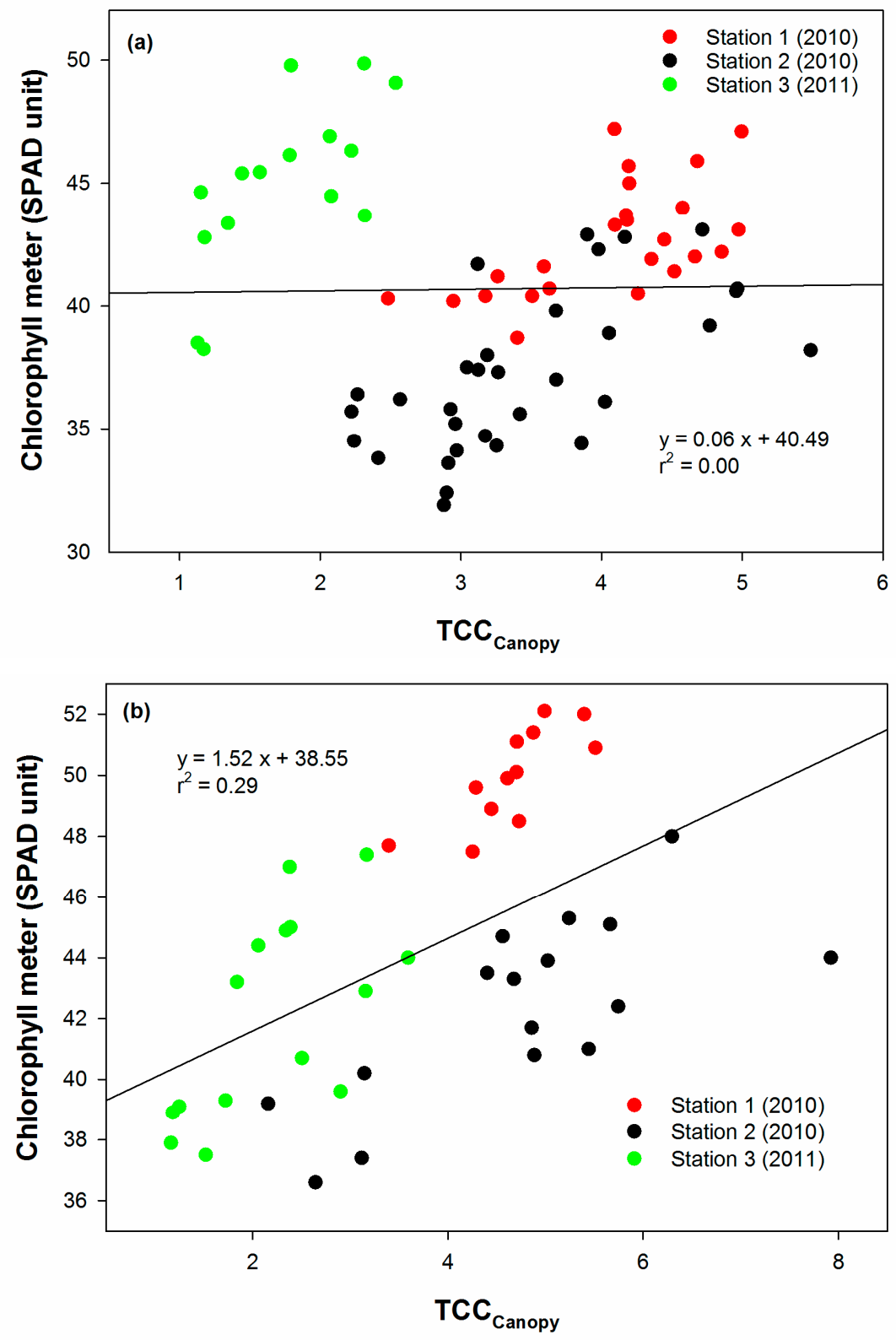

Figure 6. Linear regression between TCC Canopy and chlorophyll meter readings at (a) mid to late squaring, and (b) early flowering.

There was a distinct pattern for the $\mathrm{r}^{2}$ values of TCCs as the spatial scale increased. The best linear relationships with leaf $\mathrm{N}$ were obtained through $\mathrm{TCC}_{\text {Leaf }}$ for leaf $\mathrm{N}$ at early flowering (0.89). As the spatial scale increased to the canopy level, the $r^{2}$ value declined to 0.76 , and finally to 0.50 at the scene level (Figures 3b, 5b and $7 b$ ). The same observation could be made for the estimation of chlorophyll meter readings (Figures $4 \mathrm{~b}, 6 \mathrm{~b}$ and $8 \mathrm{~b}$ ). These results suggest that TCCLeaf is better than the other two indices at estimating leaf N. Since the GC term was present in all the TCCs, the only measurement accounted for the differences between the indices was leaf greenness. The use of 550 and $700 \mathrm{~nm}$ wavelengths (green and red-edge) to measure leaf greenness as a proxy to chlorophyll content agreed with the wavelengths reported by Buscaglia and Vasco [25] and Tarpley et al. [31]. Gitelson et al. [23] state that the use of green and red-edge wavelengths greatly improved chlorophyll estimation for the crops that they studied, due to the high saturation level for chlorophyll content and also because the light 
in these two regions penetrated deeper into the leaf. As the scale of measurements increased, additional components are present that can compromise the purity of the leaf greenness. For example, at the canopy level, measurements were affected by the complex interaction between leaves and shadow. Since spectral measurements made at the scene scale, and are influenced by multiple factors (percent GC and soil reflectance), thus results can be confounded when estimating biophysical factors. It is worth mentioning that this result disagreed with Read et al. [27], who suggest that cotton canopy reflectance has a better potential for estimating leaf $\mathrm{N}$ and chlorophyll content of cotton in comparison to leaf reflectance. Nevertheless, in arguing the overall accuracy of the TCCs, GC can be overvalued where it may work for monoculture systems in which homogenous fertilization rate and schedule is applied. While GC is an imperfect approximation of 2-dimensional LAI, it is worth noting that Muharam [30] reported that similar LAI values could have as much as $30 \%$ differences in their respective GCs.
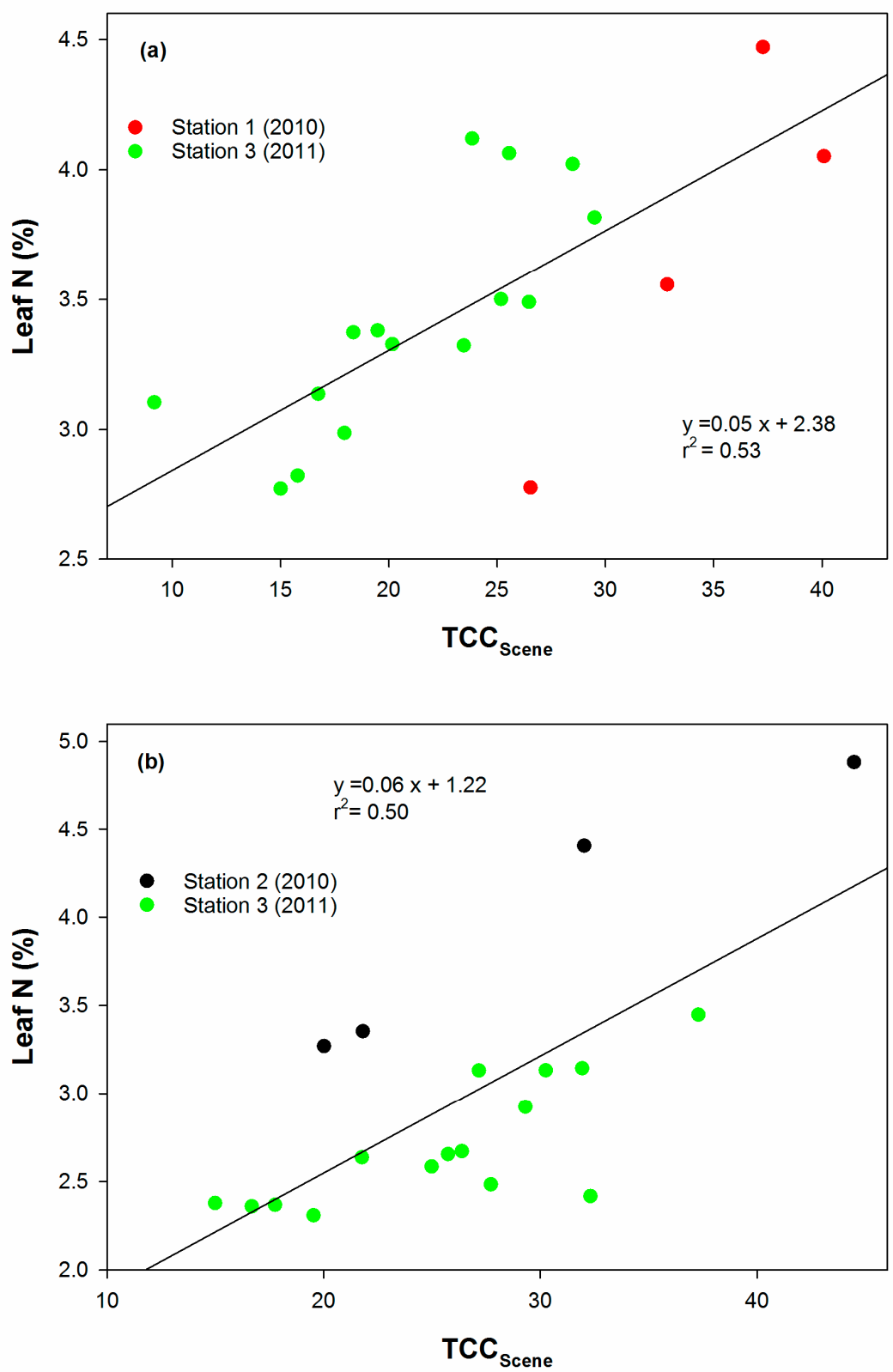

Figure 7. Linear regression between TCCscene and leaf $\mathrm{N}$ at (a) mid to late squaring, and (b) early flowering. 

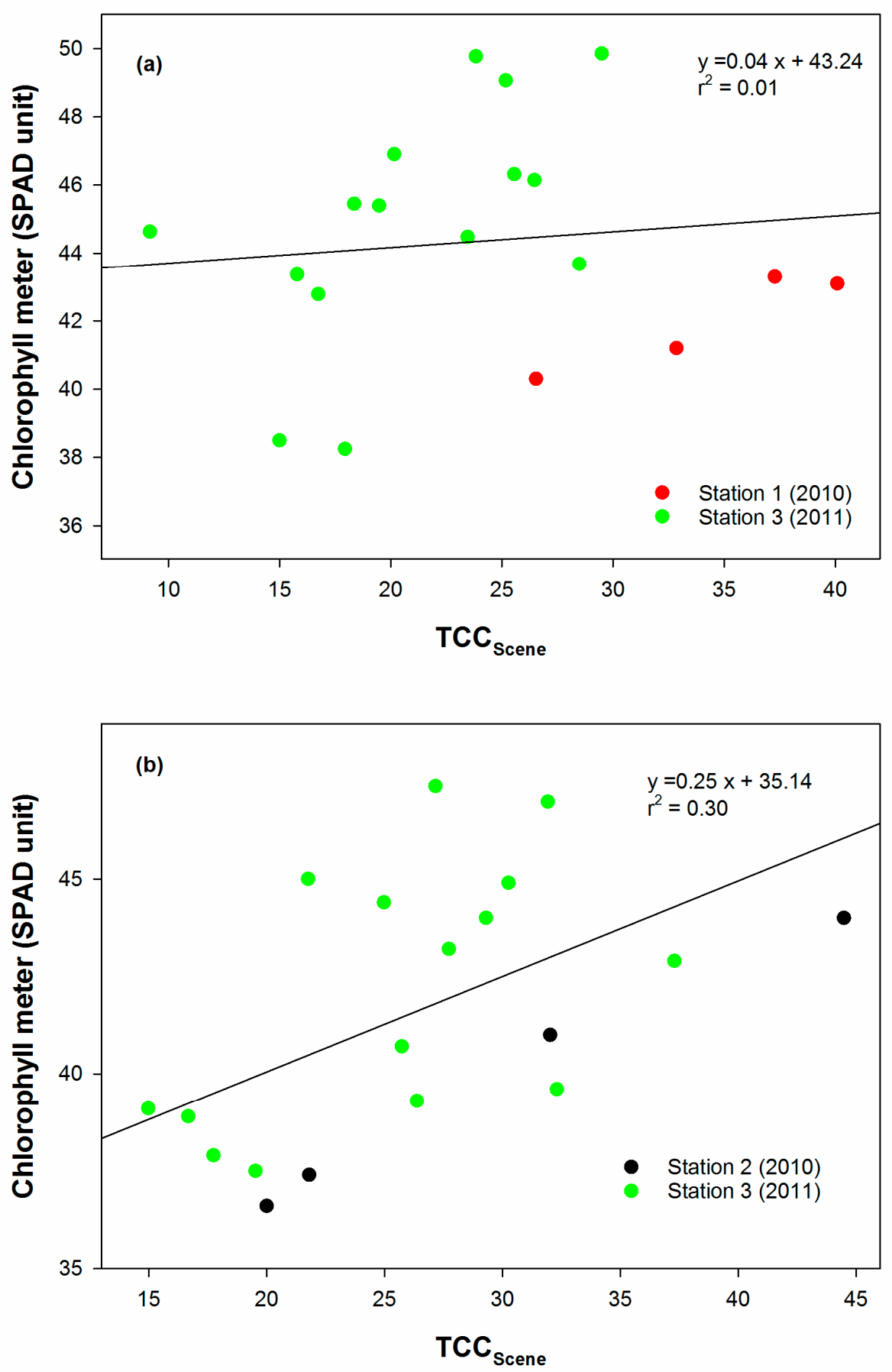

Figure 8. Linear regression between TCCscene and chlorophyll meter readings at (a) mid to late squaring, and (b) early flowering.

A strong $\mathrm{r}^{2}$ value for relationships involving TCC Canopy also suggests that the combination of 600 and $700 \mathrm{~nm}$ (yellow and red-edge wavelengths) was successful in estimating leaf greenness at the canopy level. While the use of red-edge wavelengths to estimate cotton leaf tissue $\mathrm{N}$ or chlorophyll content at the canopy scale is not new [28,31], the use of reflectance at $600 \mathrm{~nm}$ wavelengths could improve the estimation scheme. The relationship between $\mathrm{TCC}_{\text {Canopy }}$ and leaf $\mathrm{N}$ was slightly lower than $\mathrm{TCC}_{\text {Leaf, }}$ suggesting that this index could serve as an alternative in events where individual leaf reflectance is inconvenient to obtain. 
Total Chlorophyll Content measured at the scene scale (TCCScene) was found to perform very poorly in comparison to the other two indices. At the scene scale, due to the inclusion of additional elements in the reflectance measurements, the estimations of canopy information from the scene measurement was less accurate than the measurements of the canopy scale. With low percent GC as part of scene reflectance, the signal obtained at the scene scale is not strongly associated with the biophysical properties of the canopy. As expected, this condition could have hindered accurate estimation of chlorophyll or $\mathrm{N}$ estimation, and thus contributed to the lowest $\mathrm{r}^{2}$ value. Further analysis was carried out to compare $\left(\mathrm{R}_{\mathrm{NIR}}-\mathrm{R}_{\mathrm{RED}}\right)_{\text {canopy,measured }}$ and

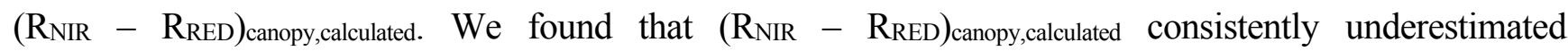
$\left(\mathrm{R}_{\mathrm{NIR}}-\mathrm{R}_{\mathrm{RED}}\right)_{\text {canopy,measured }}$ with an RMSE of 0.085 .

\section{Conclusions}

Results from this study demonstrate that the novel concept of combining measurements obtained at different spatial levels has a strong potential for use in estimating plant $\mathrm{N}$ status, specifically leaf $\mathrm{N}$. The utilization of ground cover to augment reflectance measurement made at the scene level synthesized the plant physiological parameter affected by $\mathrm{N}$ treatments into the remote sensing indices. Most important, ground cover could be an effective growth parameter that can be used to complement spectral measurements for estimating leaf $\mathrm{N}$. In general, results involving the TCCs emphasize the necessity of understanding the effects of spatial scales in developing indices for estimating crop biophysical information.

\section{Acknowledgments}

The main author would like to thank Universiti Putra Malaysia and Ministry of Education, Malaysia for study leave and scholarship.

\section{Author Contributions}

Farrah Melissa, Stephan J. Maas and Kevin F. Bronson conceived and designed the experiments, Farrah Melissa conducted the experiments, analyzed the data, developed the models and wrote the paper, Stephan J. Maas, Kevin F. Bronson and Tina Delahunty contributed revising model and the paper.

\section{Conflicts of Interest}

The authors declare no conflict of interest.

\section{References}

1. Elliott, F.C.; Hoover, M.; Porter, W.K. Advances in Production and Utilization of Quality Cotton: Principles and Practices; Iowa State University Press: Ames, Iowa, USA, 1968; p. 532.

2. Jackson, E.B.; Tilt, P.A. Effects of irrigation intensity and nitrogen level on the performance of eight varieties of upland cotton, Gossypium hirsutum L. Agron. J. 1968, 60, 13-17.

3. Leffler, H.R.; Elmore, C.D.; Hesketh, J.D. Seasonal and fertility-related changes in cotton seed protein quantity and quality. Crop Sci. 1977, 17, 953-956. 
4. Tharp, W.H. The cotton plant. U.S. Department of Agriculture Agricultural Handbook No. 178. 1960. Available online: http://naldc.nal.usda.gov/naldc/download.xhtml?id=CAT87208829\& content=PDF (accessed on 5 May 2015).

5. Wadleigh, C.W. Growth Status of the Cotton Plant as Influenced by the Supply of Nitrogen; Arkansas Agricultural Experiment Station: Fayetteville, AR, USA, 1944.

6. Walter, H.; Gausman, H.W.; Rittig, F.R.; Namkin, L.M.; Escobar, D.E.; Rodriguez, R.R. Effects of mepiquat chloride on cotton plant leaf and canopy structure and dry weights of its components. In Proceeding of 1980 Beltwide Cotton Production Research Conference, St. Louis, MO, USA, 6-10 January 1980.

7. Jackson, B.S.; Gerik, T.J. Boll shedding and boll load in nitrogen-stressed cotton. Agron. J. 1990, $82,483-488$.

8. Oosterhuis, D.M. Physiology and nutrition of high yielding cotton in the USA. Inf. Agron. Piracicaba 2001, 95, 18-24.

9. Silvertooth, J.C.; Bronson, K.F.; Norton, E.R.; Mikkelsen, R. Nitrogen utilization by Western U.S. cotton. Better Crop. Plant Food 2011, 95, 21-23.

10. Bronson, K.F.; Chua, T.T.; Booker, J.D.; Keeling, J.W.; Lascano, R.J. In-season nitrogen status sensing in irrigated cotton. II. Leaf nitrogen and biomass. Soil Sci. Soc. Am. J. 2003, 67, 1439-1448.

11. Bronson, K.F.; Onken, A.B.; Keeling, J.W.; Booker, J.D.; Torbert, H.A. Nitrogen response in cotton as affected by tillage system and irrigation level. Soil Sci. Soc. Am. J. 2001, 65, 1153-1163.

12. Wiedenfeld, B.; Wallace, B.W.; Hons, F. Indicators of cotton nitrogen status. J. Plant Nutr. 2009, $32,1353-1370$.

13. Rosolem, C.A.; van Meliss, V. Monitoring nitrogen nutrition in cotton. Rev. Bras. Cienc. Solo. 2010, 34, 1601-1607.

14. Malavolta, E.; Nogueira, N.G.L.; Heinrichs, R.; Higashi, E.N.; Rodríguez, V.; Guerra, E.; de Oliveira, S.C.; Cabral, C.P. Evaluation of nutritional status of the cotton plant with respect to nitrogen. Commun. Soil Sci. Plant Anal. 2004, 35, 1007-1019.

15. Osborne, S.L.; Schepers, J.S.; Francis, D.D.; Schlemmer, M.R. Detection of phosphorus and nitrogen deficiencies in corn using spectral radiance measurements. Agron. J. 2002, 94, 1215-1221.

16. Peterson, T.A.; Blackmer, T.M.; Francis, D.D.; Schepers, J.S. Using a chlorophyll meter to improve $\mathrm{N}$ management. Historical Materials from University of Nebraska-Lincoln Extension. 1993. Available online: http://digitalcommons.unl.edu/cgi/viewcontent.cgi?article=2349\& context $=$ extensionhist (accessed on 16 December 2013).

17. Chappelle, E.W.; Kim, M.S.; McMurtrey, J.E. Ratio analysis of reflectance spectra (RARS): An algorithm for the remote estimation of the concentrations of chlorophyll $a$, chlorophyll $b$, and carotenoids in soybean leaves. Remote Sens. Environ. 1992, 39, 239-241.

18. Yoder, B.; Pettigrew-Crosby, R. Predicting nitrogen and chlorophyll content and concentrations from reflectance spectra (400-2500 nm) at leaf and canopy scales. Remote Sens. Environ. 1995, 53, 199-211.

19. Datt, B. Remote sensing of chlorophyll $a$, chlorophyll $b$, chlorophyll $a+b$, and total carotenoid content in eucalyptus leaves. Remote Sens. Environ. 1998, 66, 111-121. 
20. Blackburn, G.A. Quantifying chlorophyll and carotenoid at leaf and canopy scales: An evaluation of some hyperspectral approaches. Remote Sens. Environ. 1998, 66, 273-285.

21. Gitelson, A.A.; Merzlyak, M.N. Remote sensing of chlorophyll concentration in higher plant leaves. Adv. Space Res.1998, 22, 689-692.

22. Sims, D.A.; Gamon, J.A. Relationship between leaf pigment content and spectral reflectance across a wide range species, leaf structures and development stages. Remote Sens. Environ. 2002, 81, 337-354.

23. Gitelson, A.A.; Gritz. Y.; Merzlyak, M.N. Relationships between leaf chlorophyll content and spectral reflectance and algorithms for non-destructive chlorophyll assessment in higher plant leaves. J. Plant Physiol. 2003, 160, 271-282.

24. Clay, D.E.; Kim, K.; Chang, J.; Clay, S.A.; Dalsted, K. Characterizing water and nitrogen stress in corn using remote sensing. Agron. J. 2006, 98, 579-587.

25. Buscaglia, H.J.; Varco, J.J. Early detection of cotton leaf nitrogen status using leaf reflectance. J. Plant Nutr. 2002, 25, 2067-2080.

26. Zhao, D.; Reddy, K.R.; Kakani, V.G.; Read, J.J.; Koti, S. Selection of optimum reflectance ratios for estimating leaf nitrogen and chlorophyll concentrations of field grown cotton. Agron. J. 2005, 97, 89-98.

27. Read, J.J.; Tarpley, L.M.; McKinion, J.M.; Reddy, K.R. Narrow-waveband reflectance ratios for remote estimation of nitrogen status in cotton. J. Environ. Qual. 2002, 31, 1436-1452.

28. Li, H.; Lascano, R.J.; Barnes, E.M.; Booker, J.; Wilson, L.T.; Bronson, K.F.; Segarra, E. Multispectral reflectance of cotton related to plant growth, soil water, texture, and site elevation. Agron. J. 2001, 93, 1327-1337.

29. Bronson, K.F.; Booker, J.D.; Keeling, J.W.; Boman, R.K.; Wheeler, T.A.; Lascano, R.J.; Nichols, R.L. Cotton canopy reflectance at landscape scale as affected by nitrogen fertilization. Agron. J. 2005, 98, 579-587.

30. Muharam, F.M. Nitrogen Nutrition Estimation of Cotton Using Greenness and Ground Cover. Ph.D. Thesis, Texas Tech University, Lubbock, TX, USA, 2012.

31. Tarpley, L.; Reddy, K.R.; Sassenrath-Cole, G.F. Reflectance indices with precision and accuracy in predicting cotton leaf nitrogen concentration. Crop Sci. 2000, 40, 1814-1819.

32. Broge, N.H.; Leblanc, E. Comparing prediction power and stability of broadband and hyperspectral vegetation indices for estimation of green leaf area index and canopy chlorophyll density. Remote Sens. Environ. 2000, 76, 156-172.

33. Daughtry, C.S.T.; Walthall, C.L.; Kim, M.S.; de Colstoun, E.B.; McMurtrey, J.E. III. Estimating corn leaf chlorophyll concentration from leaf and canopy reflectance. Remote Sens. Environ. 2000, 74, 229-239.

34. Haboudane, D.; Miller, J.R.; Tremblay, N.; Zarco-Tejada, P.J.; Dextraze, L. Integrated narrow-band vegetation indices for prediction of crop chlorophyll content for application to precision agriculture. Remote Sens. Environ. 2002, 84, 416-366.

35. Haboudane, D.; Miller, J.R.; Pattey, E.; Zarco-Tejada, P.J.; Stachan, I.B. Hyperspectral vegetation indices and novel algorithms for predicting green LAI of crop canopies: Modeling and validation in the context of precision agriculture. Remote Sens. Environ. 2004, 90, 337-352. 
36. Haboudane, D.; Tremblay, N.; Miller, J.R.; Vigneault, P. Remote estimation of crop chlorophyll content using spectral indices derived from hyperspectral data. IEEE Trans. Geosci. Remote Sens. 2008, 46, 363-437.

37. Delegido, J.; Alonso, L.; González, G.; Moreno, J. Estimating chlorophyll content of crops from hyperspectral data using a normalized area over reflectance curve (NAOC). Int. J. Appl. Earth Obs. Geoinf. 2010, 12, 165-174.

38. Maas, S.J. Estimating cotton canopy ground cover from remotely sensed scene reflectance. Agron. $J$. 1998, 90, 384-388.

39. Maas, S.J. Structure and reflectance of irrigated cotton leaf canopies. Agron. J. 1997, 89, 54-59.

40. Verstraete, M.M.; Pinty, B. The potential contribution of satellite remote sensing to the understanding of arid lands processes. Vegetation 1991, 91, 59-72.

41. Rundquist, B.C. The influence of green vegetation fraction on spectral measurements over native tallgrass prairie. Remote Sens. Environ. 2002, 81, 129-135.

42. Ritchie, G.L.; Sullivan, D.G.; Vencill, W.K.; Bednarz, C.W.; Hook, J.E. Sensitivities of normalized difference vegetation index and a green/red ratio index to cotton ground cover fraction. Crop Sci. 2010, 50, 1000-1010.

43. Maas, S.J.; Rajan, N. Estimating ground cover of field crops using medium-resolution multispectral satellite imagery. Agron. J. 2008, 100, 320-327.

44. Muharam, F.M.; Bronson, K.F.; Maas, S.J.; Ritchie, G.L. Estimation of cotton plant nitrogen status using plant height, canopy width, and ground cover. Field Crop Res. 2014, 169, 58-69.

45. Jiang, Z.; Huete, A.R.; Chen, J.; Chen, Y.; Li, J.; Yan, G.; Zhang, X. Analysis of NDVI and scaled difference vegetation index retrievals of vegetation fraction. Remote Sens. Environ. 2006, 101, 366-378.

46. Peng, S.; Garcia, F.C.; Laza, R.C.; Cassman, K.G. Adjustment for specific leaf weight improves chlorophyll meter's estimation of rice leaf nitrogen concentration. Agron. J. 1993, 85, 987-990.

47. Wood, C.W.; Tracy, P.W.; Reeves, D.W.; Edmisten, K.L. Determination of cotton nitrogen status with a hand-held chlorophyll meter. J. Plant Nutr. 1992, 15, 1435-1448.

(C) 2015 by the authors; licensee MDPI, Basel, Switzerland. This article is an open access article distributed under the terms and conditions of the Creative Commons Attribution license (http://creativecommons.org/licenses/by/4.0/) 